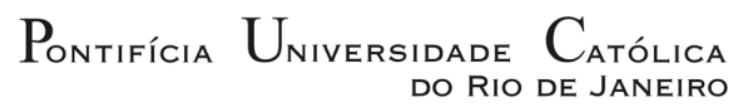
DO RIO DE JANEIRO

Deborah Chagas Christo

Estrutura e funcionamento do campo de produção de objetos do vestuário no Brasil

Tese de Doutorado

Tese apresentada ao Programa de PósGraduação em Design do Departamento de Artes \& Design do Centro de Teologia e Ciências Humanas da Pontifícia Universidade Católica do Rio de Janeiro como requisito parcial para obtenção do título de Doutor em Design.

Orientador: Prof. Alberto Cipiniuk 
Deborah Chagas Christo

\section{Estrutura e funcionamento do campo de produção de objetos do vestuário no Brasil}

Tese apresentada ao Programa de Pós-Graduação em Design da PUC-Rio como requisito parcial para obtenção do grau de Doutor em Design. Aprovada pela Comissão Examinadora abaixo assinada.

Prof. Alberto Cipiniuk

Orientador

Departamento de Artes \& Design - PUC-Rio

Prof. - Leila Lemgruber Queiroz Departamento de Artes \& Design - PUC-Rio

Prof.. Fernanda de Abreu Cardoso Universidade Federal do Rio de Janeiro - UFRJ

Prof.. Kathia Castilho Cunha Universidade Anhembi Morumbi

Prof. Marcelo Vianna Lacerda de Almeida Universidade Federal de Juiz de Fora - UFJF

Prof. - Denise Berruezo Portinari Coordenadora Setorial do Centro de Teologia

E Ciências Humanas - PUC-Rio

Rio de Janeiro, 05 de abril de 2013 
Todos os direitos reservados. É proibida a reprodução total ou parcial do trabalho sem autorização da universidade, da autora e do orientador.

\section{Deborah Chagas Christo}

Mestre em Design pela Pontifícia Universidade Católica do Rio de Janeiro (PUC-Rio) e graduada em Desenho Industrial e Comunicação Visual pela Escola Superior de Desenho Industrial (ESDI) da Universidade Estadual do Rio de Janeiro (UERJ). Professora e pesquisadora com interesse na delimitação, estrutura e funcionamento do campo do design e nas relações entre design, moda e arte.

Ficha Catalográfica

Christo, Deborah Chagas

Estrutura e funcionamento do campo de produção de objetos do vestuário no Brasil / Deborah Chagas Christo ; orientador: Alberto Cipiniuk. - 2013.

$146 \mathrm{f.} ; 30 \mathrm{~cm}$

Tese (doutorado)-Pontifícia Universidade Católica do Rio de Janeiro, Departamento de Artes e Design, 2013.

Inclui bibliografia

1. Artes e design - Teses. 2. Design. 3. Moda. 4. Vestuário. 5. Campo de produção de objetos do vestuário. I. Cipiniuk, Alberto. II. Pontifícia Universidade Católica do Rio de Janeiro. Departamento de Artes \& Design. III. Título. 
Para Flávio e Joaquim, meus amores, para Edna, minha base, afeto e coração, e para Irene, presença constante... 


\section{Agradecimentos}

Ao Professor Alberto Cipiniuk, pela parceria, apoio, presença e pelas jabuticabeiras balançadas...

Ao Flávio por me incentivar a não deixar de tentar, por ser meu companheiro, cúmplice, amigo, amante, amor... e por me amar... e me deixar amá-lo...

Ao Joaquim pelos momentos de espera paciente para brincar... e pelos fartos sorrisos e beijos...

À Edna pelo apoio e ajuda constante e incondicional, pelo incentivo, pelo amor... mas também pelas correções e revisões.

À Eva que cuidou de Joaquim, do Flávio e de mim...

À Ester e ao "familião", Camila, Felipe, Valéria, Alexandre, Vitória, Natália, Vanessa, Renato, Fernando, Marilene, João Miguel e Ana Clara pelo apoio e... pelos momentos de descontração...

À Adriana pela cumplicidade e pelos passeios com seu afilhado...

Aos amigos Luisa Meirelles, Luciana Montenegro e Zé Luiz pelas conversas na cantina, no café ou no Floresta sobre os limites da moda, do design e da sociedade.

Ao GRUDAR e ao MoDuS pelo espaço para pensar, trocar e resistir.

Ao SENAI CETIQT que recolocou a moda na minha vida.

Aos alunos que me trouxeram suas perguntas e inquietações.

Aos colegas e amigos professores que eu conheci no SENAI CETIQT que me ensinaram muito sobre o mundo da moda

À Káthia Castilho, Maria de Fátima, Rosane Preciosa, Cristiane Mesquita, Maria Claudia Bonadio, Dorotéia Pires e todo o comitê organizador do $1^{\circ}$ Colóquio de Moda que receberam esta designer no mundo da moda.

Aos professores e funcionários do Departamento de Artes e Design da PUC-Rio.

À PUC-Rio, pelos auxílios concedidos. 


\section{Resumo}

Christo, Deborah Chagas; Cipiniuk, Alberto (orientador). Estrutura e funcionamento do campo de produção de objetos do vestuário no Brasil. Rio de Janeiro, 2013. 146p. Tese de Doutorado - Departamento de Artes \& Design, Pontifícia Universidade Católica do Rio de Janeiro.

Um designer de moda, ou estilista, como qualquer outro designer, precisa ter conhecimento sobre os diversos fatores que podem interferir na configuração de um objeto, ou seja, ter conhecimento sobre as demandas dos usuários e dos produtores, a forma, os processos criativos, os materiais e processos de fabricação, os custos de produção, etc. Porém, apesar do projeto de um objeto do vestuário ser, aparentemente, muito semelhante ao projeto de qualquer outro objeto pertencente ao campo do design, a criação, desenvolvimento e produção de objetos do vestuário vinculados à noção de moda, no Brasil, só passou a ser pensada e considerada como atividade pertencente ao campo de atuação de um designer no final da década de 1990 e início do século XXI. Ainda assim, esta incorporação apresentou, e ainda apresenta, conflitos e reações tanto dos produtores de objetos do vestuário em relação às noções e valores vinculadas ao campo do design, quanto das instituições e agentes tradicionalmente pertencentes ao campo do design em relação às noções e valores associadas ao fenômeno moda e à produção de objetos do vestuário. Assim, se considerarmos que o desenvolvimento de objetos do vestuário e de objetos tradicionalmente pertencentes ao campo do design possui uma estrutura muito semelhante, é possível afirmar que, objetivamente, não existe, e, provavelmente, nunca existiu, propriamente uma divisão entre o campo do design de objetos do vestuário e o campo do design. Porém, no Brasil, existia uma noção que posicionava o objeto do vestuário vinculado à noção de moda como algo não pertencente ao campo do design e que, a partir do final da década de 1990 e início do século XXI, começou a mudar, indicando mudanças e transformações na própria estrutura e 
funcionamento do campo de produção de objetos do vestuário no Brasil. Desta forma, esta pesquisa de doutorado analisa, utilizando como fundamentação teórica a obra de Pierre Bourdieu, a constituição, estrutura e funcionamento deste campo, no Brasil, analisando como as posições e relações entre os produtores, receptores e as instituições de legitimação, reprodução e consagração do campo, atuam e interferem nas noções e valores específicos do campo, nas práticas associadas aos agentes deste campo e, consequentemente, na produção dos objetos de vestuário no Brasil e na delimitação e definição do campo de atuação de um designer de vestuário, nomeado atualmente como designer de moda.

\section{Palavras-chave}

Design; Moda; Vestuário; Campo de produção de objetos do vestuário. 


\section{Abstract}

Christo, Deborah Chagas; Cipiniuk, Alberto (Advisor). Structure and Functioning of Clothing Objects Production Field in Brazil. Rio de Janeiro, 2013. 146p. Departamento de Artes \& Design, Pontifícia Universidade Católica do Rio de Janeiro.

A fashion designer, like any other designer, need to have knowledge about the various factors that can affect the object configuration, need to have knowledge about the users and producers demands, the form, the creative processes, the materials and manufacturing processes, the production costs, etc. However, despite the clothing object being, apparently, very similar to the project of any object belonging to the design field, creation , development and production of clothing objects linked to the notion of fashion in Brazil only became be thought and considered as an activity belonging to the design field in the late 1990s and early twenty-first century. Nevertheless, this incorporation presented, and still presents, conflicts and reactions of both, clothing object producers regarding concepts and values related to the design field, as well as institutions and agents traditionally belonging to the design field in relation to the notions and values associated with fashion phenomenon and with the garment objects production. Thus, if we consider that the development of clothing objects and of objects traditionally belonging to the design field has a very similar structure, we can say that, objectively, there is not, and probably never existed, itself a division between the clothing objects design field and the design field. However, in Brazil, there was a notion that the clothing object linked to the notion of fashion is something not belonging to the design field and, from the late 1990s and early twenty-first century, began to change, indicating changes in the structure and functioning of the clothing objects production field. Therefore, this $\mathrm{PhD}$ research analyzes, using as the theoretical work of Pierre Bourdieu, the constitution, structure and functioning of this field in Brazil, analyzing how the positions and relationships between producers, receivers and legitimation, reproduction and 
consecration institutions of the field work and interfere with specific field notions and values, with the practices associated with this field agents and, consequently, the clothing objects production in Brazil and the delineation and definition of the clothing design field, named currently as a fashion designer .

\section{Keywords}

Design; Fashion; Apparel; Clothing objects production field. 


\section{Sumário}

1. Introdução 11

2. Moda: Definições e conceitos 23

3. Constituição do campo de produção

de objetos do vestuário no Brasil

4. Estrutura e funcionamento do campo de produção de objetos de vestuário no Brasil

5. Conclusão

6. Referências Bibliográficas 